\title{
Lizard assemblages on sandy coastal plains in southeastern Brazil: An analysis of occurrence and composition, and the role of habitat structure
}

\author{
JANE C.F. OLIVEIRA ${ }^{1}$, JULIANE PEREIRA-RIBEIRO ${ }^{1}$, GISELE R. WINCK ${ }^{2}$ and CARLOS F.D. ROCHA ${ }^{1}$ \\ ${ }^{1}$ Departamento de Ecologia, Instituto de Biologia Roberto de Alcântara Gomes, Universidade do Estado do \\ Rio de Janeiro, Rua São Francisco Xavier, 524, Maracanã, 20550-019 Rio de Janeiro, RJ, Brazil \\ ${ }^{2}$ Laboratoire d'Ecologie Alpine, UMR-CNRS-UGA-USMB 5553, \\ Université Grenoble Alpes, 38058 Grenoble Cedex 9, France \\ Manuscript received on May 30, 2017; accepted for publication on May 7, 2018
}

\begin{abstract}
How to cite: OLIVEIRA JCF, PEREIRA-RIBEIRO J, WINCK GR AND ROCHA CFD. 2019. Lizard assemblages on sandy coastal plains in southeastern Brazil: An analysis of occurrence and composition, and the role of habitat structure. An Acad Bras Cienc 91: e20170403. DOI 10.1590/0001-3765201820170403.
\end{abstract}

\begin{abstract}
Data on the structure of lizard communities in the different biomes and ecosystems of Brazil are still limited. In this study, we related the species richness, abundance and the spatial occurrence of lizards to the structure of the vegetation found on the coast of the state of Espírito Santo, southeastern Brazil, to determine whether habitat influences the structure of lizard communities. We conducted fieldwork in 2012, 2013 and 2014, collecting data in standardized samples. We analyze whether variables of vegetation structure influenced species richness and abundance, using Generalized Linear Models (GLMs). We recorded 12 lizard species from eight families. In general, species richness and abundance were similar among sites. Locally, we recorded the highest species richness in shrubby vegetation, open Clusia vegetation, and the restinga forest zone. Bromeliads explained the occurrence of teiids, although there was no systematic relationship between species richness and vegetation structure. Our results provide important insights into the characteristics of the lizard communities found on sandy coastal plains and contribute to the conservation of these species in these ecosystems.
\end{abstract}

Key words: community ecology, community structure, mesohabitat, Squamata.

\section{INTRODUCTION}

In Ecology, understanding how species composition, abundance and their interactions are organized is a fundamental issue (Sutherland et al. 2013). On geographical scale, physical barriers, local extinctions and recolonizations (Hanski 1994), as well as the dispersal capacity of species (Pulliam 2000) are fundamental to the formation

Correspondence to: Jane C. F. de Oliveira

E-mail: janeherpeto@gmail.com

ORCid: http://orcid.org/0000-0001-5084-1420 of assemblages and their spatial and temporal variation (Mouquet and Loreau 2003). Furthermore, historical factors may also combine to influence the spatial and temporal variation found in communities (Nekola and White 1999). On regional and local scales, assemblage composition is fundamental to ecosystems dynamics and functioning (e.g. Wedin and Tilman 1990), and plays a fundamental role in the stability, resilience and invasiveness of these systems (e.g. Tilman 1999).

Brazilian sandy coastal plain ecosystems harbor a considerable diversity of lizard species, 
compared with the Atlantic Rainforest sensu stricto (e.g. Rocha et al. 2003). These coastal plains were formed during the Holocene from fluvial sediments deposited over the past 6.5 thousand years (Suguio and Tessler 1984) and the phytophysiognomy of their vegetation is usually related by local topography, and may vary from herbaceous vegetation and grasses to trees of up to five meters in height (Pereira 1990). Lizard assemblages vary among sites, but typically comprise both endemic and wide-ranging species (Rocha et al. 2005, Dias and Rocha 2014), despite their varying habitat requirements (e.g. Rocha and Bergallo 1997, Vitt et al. 2007, Dias and Rocha 2014). The variation in the composition of the lizard communities among Brazilian sandy coastal plains has been evaluated in relation to habitat structure and temporal changes (e.g. Rocha and Bergallo 1997, Dias and Rocha 2014). These studies also found some degree of turnover among sites and suggested that habitat structure influenced part of the variation observed in the composition of the lizard species.

In the present study, then, we evaluated the structure of lizard assemblages in five remnants of the sandy coastal plain of southeastern Brazil. Our principal hypothesis is that these lizard communities are structured primarily by local habitat factors. Specifically, we aimed to analyze (1) the difference in species richness and abundance among lizard assemblages; (2) the difference in habitat structure among sites; (3) the extent to which lizard assemblages vary among mesohabitats and sites; and (4) whether there is a relationship between species richness and abundance and vegetation structure.

\section{MATERIALS AND METHODS}

We analyzed lizard species richness and community composition in remnants of five sandy coastal plains in southeastern Brazil, in the state of Espírito Santo. The sites were (datum WGS84): Praia das
Neves (PN) (21 $\left.{ }^{\circ} 13^{\prime} \mathrm{S}, 40^{\circ} 57^{\prime} \mathrm{W}\right)$, Paulo Cesar

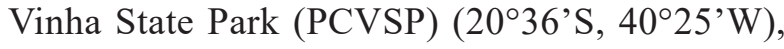
Comboios Biological Reserve (CBR) (1940’S, 3953'W), Conceição da Barra Environmental Protection Area (CBEPA) $\left(18^{\circ} 37^{\prime} \mathrm{S}, 39^{\circ} 44^{\prime} \mathrm{W}\right)$, and Itaúnas State Park (ISP) (18²4'S, 3942’W) (Figure 1). The structure of the vegetation on the sandy coastal plains varies according to the distance from the seashore, creating distinct mesohabitats (vegetation zones) (Pereira 1990). For the purposes of our study, we considered four zones: (i) beach vegetation, comprising herbaceous vegetation near the sea; (ii) shrubby vegetation, composed of low-lying bushes, cacti, and bromeliads; (iii) open Clusia zone, comprising taller bushes, with arboreal plants (Clusia spp.) grouped in widelyspaced clusters, with high densities of bromeliads, and (iv) restinga forest, composed of a continuous canopy of relatively short trees, in comparison with typical rainforest (e.g. Araújo and Henriques 1984, Bastazini et al. 2007, Oliveira et al. 2017).

We collected data at each site during two periods in the rainy season (from November to March) and two periods in the dry season (from May to July) in 2012, 2013 and 2014/1. At each site, we conducted 15 one-hour transects by visual search (Campbell and Christman 1982) in each mesohabitat (a total of 60 hours at each site). Transects were at least $50 \mathrm{~m}$ apart, whenever possible, and parallel to the beach line. We minimized the pseudo-replication of individuals by establishing this distance between transects, as well as alternating the sites sampled during the study, with an interval of at least three months between samples. As we did not use markrecapture methods during this study, it is possible that some individuals were visualized more than once, although, as we did not estimate population size, but only the abundance of individuals at the time of the sample, this was not considered to be problematic. We standardized sampling effort from 0800 a.m. to 0100 p.m., the period of peak activity of most lizard species (Araújo 1984, Hatano et al. 


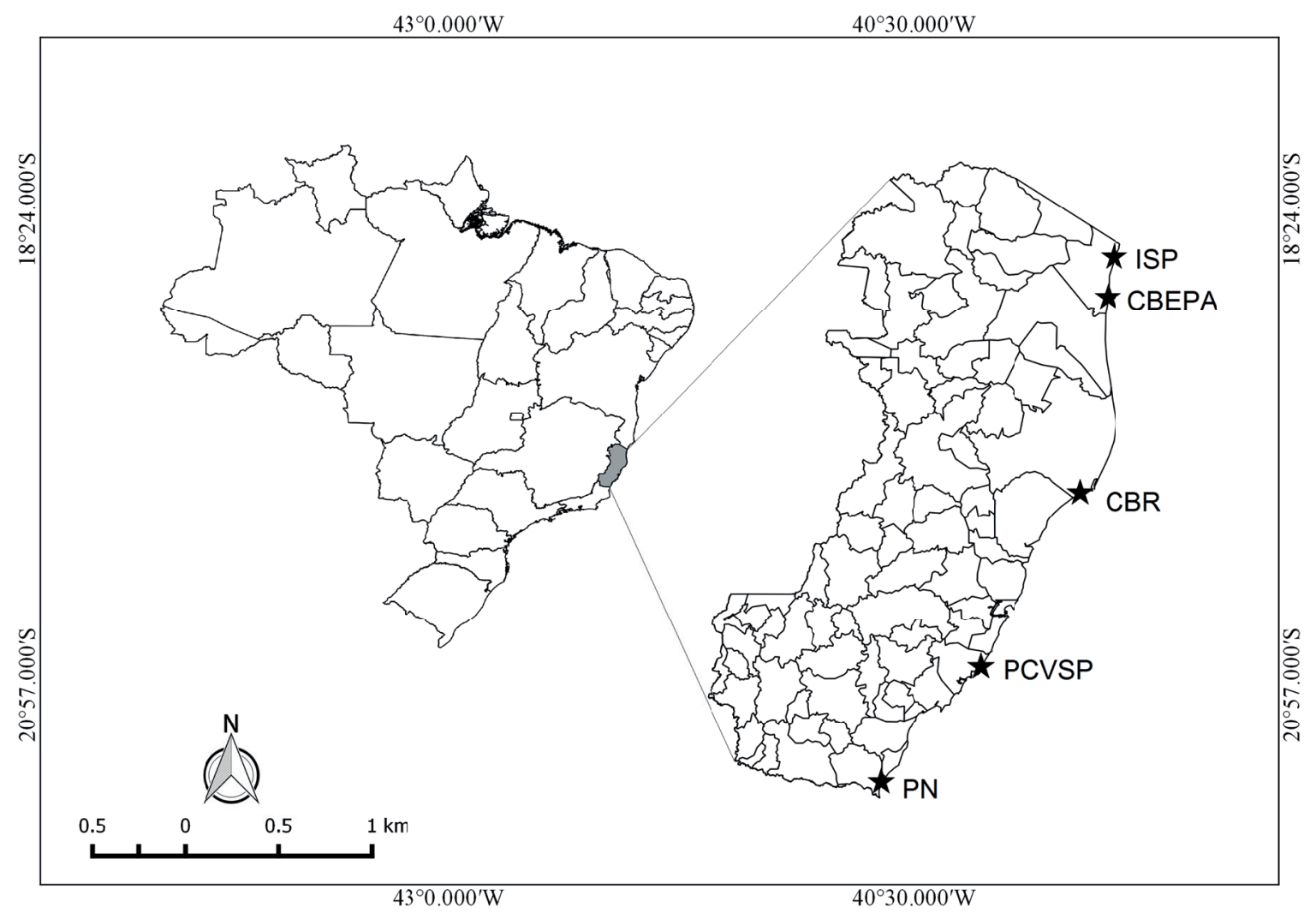

Figure 1 - Geographic location of sandy coastal plains remnants studied throughout the state of Espírito Santo, Southeastern Brazil. ISP: Itaúnas State Park; CBEPA: Conceição da Barra Environmental Protection Area; CBR: Comboios Biological Reserve; PCVSP: Paulo Cesar Vinha State Park; PN: Praia das Neves.

2001). We collect one individual of each species, at each site, as voucher specimens (Sisbio License No. 28276). These specimens were euthanized with intravenous anesthetic, fixed in $10 \%$ formalin, and preserved in $70 \%$ alcohol. The voucher specimens are deposited in the Herpetological Collection of the National Museum in Rio de Janeiro (MNRJ).

We estimated the vegetation structure at each site through a measure of heterogeneity among sample units (transects) to evaluate the effects of habitat on the structuring of the lizard assemblages. At each site, we established 20 circular plots of 2 $\mathrm{m}$ in diameter in each mesohabitat type, arranged in a straight line, 20 meters apart. In each plot, we recorded: (1) the height of the vegetation (measuring the tallest and the shortest plants); (2) the distance to the nearest shrub; (3) the stem diameter of the central plant; (4) the presence/absence and the number of cacti and bromeliads; (5) depth of the leaf litter at the central point of the plot, measured with a manual calliper; and (6) percentage canopy and ground cover, measured using a $50 \mathrm{~cm}$ x $50 \mathrm{~cm}$ square with 100 cells of $25 \mathrm{~cm}^{2}$ (Freitas et al. 2002). We measured the vegetation structure in 2013. We characterized each mesohabitat for analysis based on the mean values recorded for each variable in the 20 plots.

We tested all data for homoscedasticity of variance and calculated the species accumulation curves for each site through data permutation (1000 iterations), based on the cumulative number of species recorded (S) as a function of sampling effort (n). To evaluate the similarity in abundance and richness among sites, we used the ANOSIM 
(One-Way Similarity Analysis) permutation test on the Bray-Curtis measure (Clarke 1993) with 999 iterations. We estimated total species richness through a Bootstrap Index (Magurran 2011).

We used Generalized Linear Models (GLMs) with a Poisson distribution and log-link function (Poisson regression) to analyze whether variables of vegetation structure influenced lizard species richness and abundance. We selected variables through a stepwise regression (both backward and forward selection), using a null model (all species and no variables) for comparison, and Akaike's information criterion (AIC; Burnham and Anderson 2004) for the selection of the model for each group (lizard clades or families: all species, teiids, scincids, gekkonids, and tropidurids). We excluded Ophiodes sp., S. merianae, L. lutzae and $K$. calcarata from this analysis due to the low numbers of records ( $\mathrm{N}=1,1,2$ and 2, respectively).

To evaluate the similarity of the vegetation structure among sites, we ran a cluster analysis using the Jaccard index with simple linkage (Magurran 2011). The accumulation curve was generated in EstimateS ${ }^{\circledR} 8.0$ (Colwell 2005). We used PAST 2.17 (Hammer et al. 2001) to calculate the Jaccard indices. The ANOSIM and GLM were run in R 3.2 (Rstudio Team 2015).

\section{RESULTS}

We recorded 1529 lizards during the study, representing 12 species in eight families (Table I). The most species rich families were the Teiidae and Mabuyidae with three species each. Tropidurus torquatus was the species with the highest abundance, accounting for $58 \%$ of the records $\left(\mathrm{N}_{\log 2}=9.78\right.$, Figure 2). Salvator merianae, Liolaemus lutzae, Kentropyx calcarata, Polychrus marmoratus and Ophiodes cf. striatus were the least abundance species (Table I, Figure 2). Four species (T. torquatus, Ameiva ameiva, B. agilis and P. macrorhyncha) were recorded at all study sites, whereas three species were registered at only one site (L. lutzae at Praia das Neves, P. marmoratus at Paulo Cesar Vinha State Park, and $K$. calcarata at Itaúnas State Park) (Table I ).

Species richness did not vary significantly among sites (ANOSIM, $\mathrm{R}=-0.083 ; \mathrm{P}=0.6$ ). The highest lizard abundance was recorded at Conceição da Barra Environmental Protection Area $\left(\mathrm{N}_{\log 2}=8.79\right)$, and the lowest, at Itaúnas State Park $\left(\mathrm{N}_{\log 2}=7.31\right)$ (Table I). However, abundance did not vary significantly among sites (ANOSIM: $\mathrm{R}=$ $-0.038 ; \mathrm{p}=0.573)$. Two of the species recorded in this study (Liolaemus lutzae and Ameivula nativo) are endemic to sandy coastal plain ecosystems and have a restricted geographic distribution. Hemidactylus mabouia, an exotic gecko species from Africa was recorded at three of the five study sites.

The cumulative species curves did not reach the asymptote (Figure 3 ). The greatest similarities in the composition of the assemblages were recorded between Paulo Cesar Vinha State Park and Comboios Biological Reserve, and between the APA Conceição da Barra and Itaúnas State Park. Praia das Neves had the lowest similarity with all sites (Figure 4). Lizard species richness did not vary significantly among mesohabitats within the same site (ANOSIM; $\mathrm{R}=0.440 ; \mathrm{P}=1$ ), although abundance was greatest in the shrubby vegetation and open Clusia zones (Tables II and III). We observed T. torquatus and H. mabouia in all mesohabitats, while Ophiodes cf. striatus, $S$. merianae, $K$. calcarata and P. marmoratus were restricted to forest, and L. lutzae to the beach vegetation zone.

The vegetation structure did not vary significantly among sites (see Table SI Supplementary Material for the Mantel scores). The model that best fit the abundance of all studied species included five variables: distance to the nearest bush, the number of cacti, number of bromeliads, leaf litter depth, and canopy cover 
TABLE I

Species and their specific abundances of lizards sampled in five sandy coastal plains remnants on the coast of the state of Espírito Santo, southeastern Brazil.

\begin{tabular}{|c|c|c|c|c|c|c|}
\hline \multirow{2}{*}{ TAXA } & \multicolumn{6}{|c|}{ Sandy coastal plains } \\
\hline & PN & PCVSP & CBEPA & CBR & ISP & Total \\
\hline \multicolumn{7}{|l|}{ Squamata } \\
\hline Diploglossidae Cope, 1864 & - & - & 1 & - & - & 1 \\
\hline \multicolumn{7}{|l|}{ Ophiodes cf. striatus } \\
\hline \multicolumn{7}{|l|}{ Tropiduridae Bell in Darwin, 1843} \\
\hline Tropidurus torquatus (Wied, 1820) & 258 & 178 & 225 & 125 & 95 & 881 \\
\hline \multicolumn{7}{|l|}{ Gekkonidae Gray, 1825} \\
\hline Hemidactylus mabouia (Moreau de Jonnès, 1818) & 15 & - & 29 & - & 1 & 45 \\
\hline \multicolumn{7}{|l|}{ Teiidae Merrem, 1820} \\
\hline Ameiva ameiva (Linnaeus, 1758) & 36 & 27 & 47 & 41 & 24 & 175 \\
\hline Ameivula nativo (Rocha, Bergallo \& Peccinini-Seale, 1997) & - & 123 & 84 & 73 & 12 & 292 \\
\hline Kentropyx calcarata Spix, 1825 & - & - & - & - & 2 & 2 \\
\hline Salvator merianae (Duméril \& Bibron, 1839) & 1 & - & - & - & 1 & 2 \\
\hline \multicolumn{7}{|l|}{ Liolaemidae Frost \& Etheridge, 1989} \\
\hline Liolaemus lutzae Mertens, 1938 & 2 & - & - & - & - & 2 \\
\hline \multicolumn{7}{|l|}{ Phyllodactylidae Gamble, Bauer, Greenbaum \& Jackman, 2008} \\
\hline Gymnodactylus darwinii (Gray, 1845) & 2 & 1 & - & 6 & - & 9 \\
\hline \multicolumn{7}{|l|}{ Mabuyidae Mittleman, 1952} \\
\hline Brasiliscincus agilis (Raddi, 1823) & 15 & 8 & 13 & 17 & 22 & 75 \\
\hline Psychosaura macrorhyncha (Hoge, 1947) & 8 & 6 & 4 & 13 & 12 & 43 \\
\hline \multicolumn{7}{|l|}{ Polychrotidae Fitzinger, 1843} \\
\hline Polychrus marmoratus (Linnaeus, 1758) & - & 3 & - & - & - & 3 \\
\hline Total richness & 8 & 7 & 6 & 6 & 8 & \\
\hline Abundance & 327 & 336 & 442 & 265 & 159 & 1529 \\
\hline
\end{tabular}

PN = Praia das Neves; PCVSP = Paulo Cesar Vinha State Park; CBEPA = Conceição da Barra Environmental Protection Area; CBR $=$ Comboios Biological Reserve; ISP = Itaúnas State Park.

$\left(\mathrm{R}^{2}=0.62 ; \mathrm{F}(5,14)=4.56 ; \mathrm{P}=0.01, \mathrm{DF}=5\right.$ and 14 ; $\mathrm{AIC}=225.17$; see Supplementary Material for scores), with bromeliads and leaf litter being the most important variables $(\mathrm{P}=0.004$ and 0.03 , respectively). The best model for the Teiidae included the bromeliads, leaf litter depth, and canopy cover $\left(\mathrm{R}^{2}=0.4 ; \mathrm{F}(3,16)=3.6 ; \mathrm{P}=0.036 ; \mathrm{DF}\right.$ $=3$ and $16 ; \mathrm{AIC}=191.62)$, with bromeliads being significant $(\mathrm{P}=0.009)$, and the others marginally significant $(\mathrm{P}=0.08$ and 0.087$)$. For Scincidae, the best fit model was marginally significant, and included the shortest plant height, the diameter of the tallest plant, the distance between bushes, the number of cacti and bromeliads, leaf litter depth, and canopy cover $\left(\mathrm{R}^{2}=0.59 ; \mathrm{F}(7,12)=2.47 ; \mathrm{P}=\right.$ $0.08 ; \mathrm{DF}=7$ and $12 ; \mathrm{AIC}=142)$. Number of cacti and bromeliads were significant $(\mathrm{P}=0.03$ and 0.04 , respectively), other three variables were marginally 


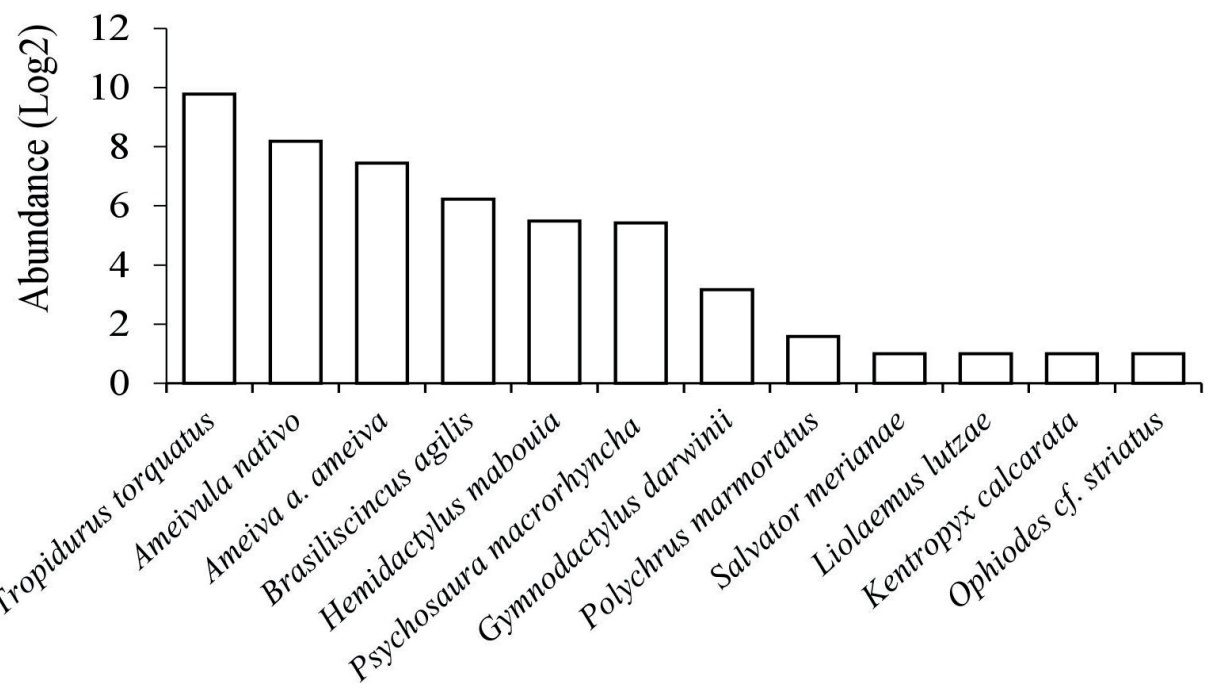

Figure 2 - Total abundance $\left(\log _{2}\right)$ of lizards recorded at: Itaúnas State Park; Conceição da Barra Environmental Protection Area; Comboios Biological Reserve; Paulo Cesar Vinha State Park and Praia das Neves. Species are ranked from highest to lowest abundance.

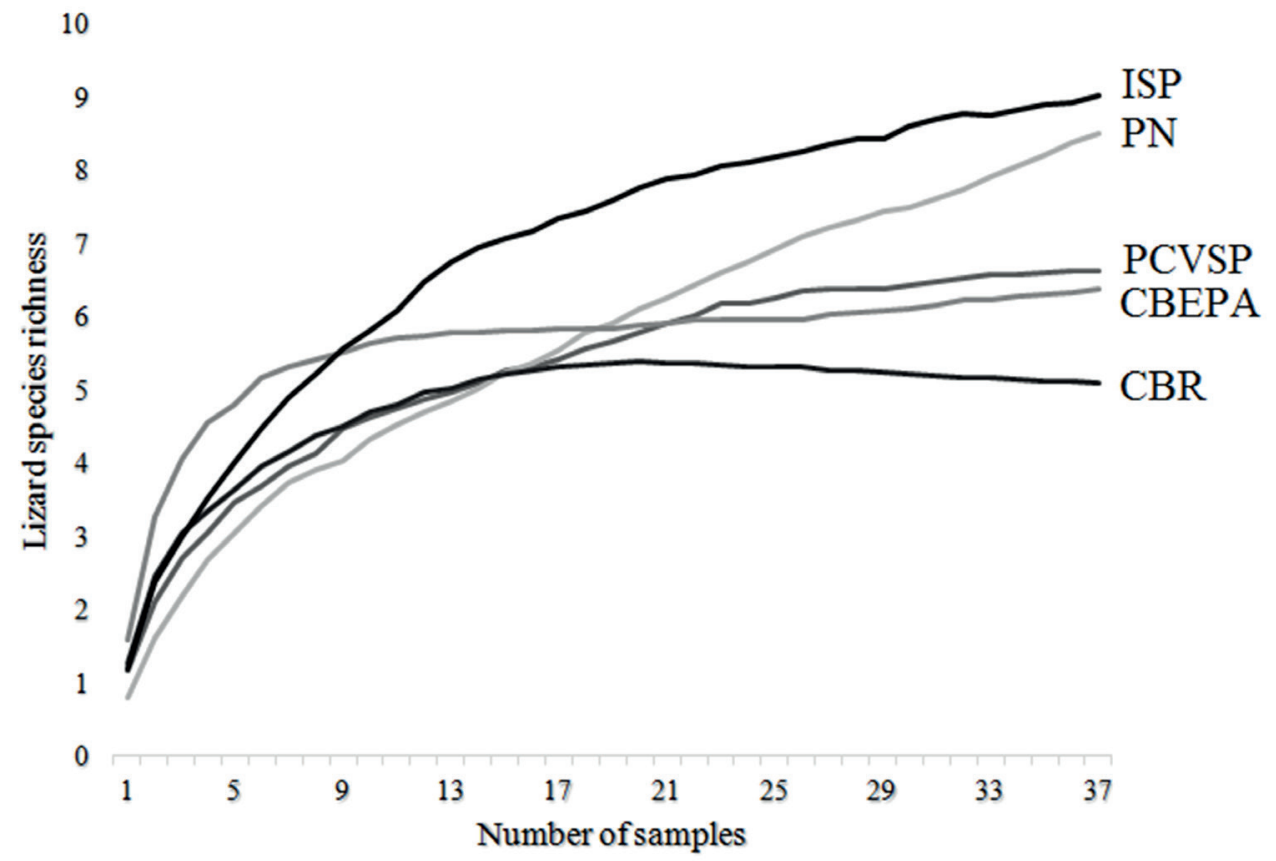

Figure 3 - Species richness curves estimated for lizards for the studied sandy coastal plains in Espírito Santo state, Brazil. ISP: Itaúnas State Park; CBEPA: Conceição da Barra Environmental Protection Area; CBR: Comboios Biological Reserve; PCVSP: Paulo Cesar Vinha State Park; PN: Praia das Neves. 


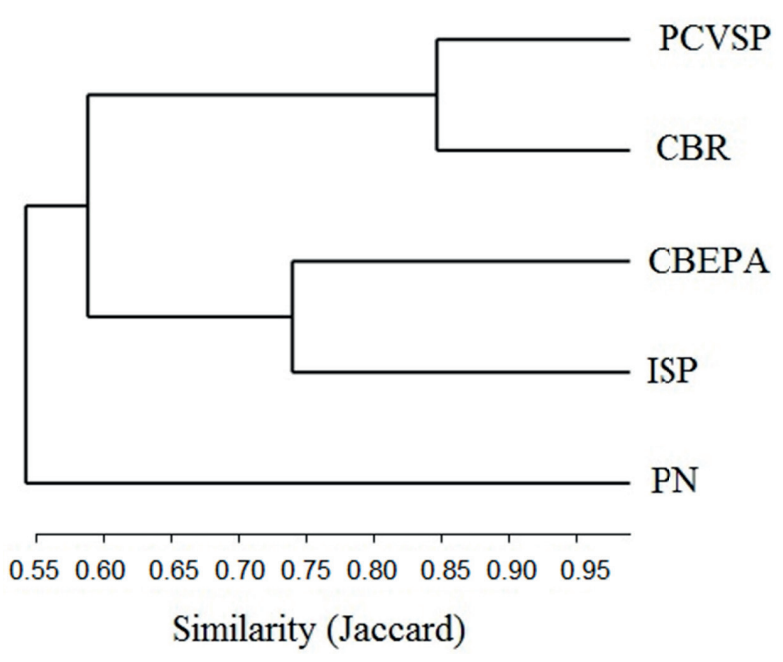

Figure 4 - Cluster analysis (Jaccard) related to the lizard species richness in the five sampled sandy coastal plains remnants on the coast of Espírito Santo state, Brazil. ISP: Itaúnas State Park; CBEPA: Conceição da Barra Environmental Protection Area; CBR: Comboios Biological Reserve; PCVSP: Paulo Cesar Vinha State Park; PN: Praia das Neves.

significant (distance between bushes $\mathrm{P}=0.06$; leaf litter depth $\mathrm{P}=0.07$; canopy cover $\mathrm{P}=0.09$ ). Plant height $(\mathrm{P}=0.14)$ and the diameter of the tallest plant $(\mathrm{P}=0.11)$ did not present significant $\mathrm{p}$-values. The best model for the gekkonid clade (H. mabouia + G. darwinii) was not statistically significant, and included the diameter of the tallest plant, and canopy and ground cover $\left(\mathrm{R}^{2}=0.28 ; \mathrm{F}(3,16)=2.1\right.$; $\mathrm{P}=0.14 ; \mathrm{DF}=3$ and $16 ; \mathrm{AIC}=136)$, although ground cover was significant $(\mathrm{P}=0.05)$. The best model for T. torquatus (Tropiduridae) included the distance between bushes, the number of cacti and bromeliads, leaf litter depth, and canopy cover $\left(\mathrm{R}^{2}=\right.$ $0.65 ; \mathrm{F}(5,14)=5.15 ; \mathrm{P}=0.007 ; \mathrm{DF}=5$ and $14 ; \mathrm{AIC}$ $=201$; Table SII), and canopy cover was the only variable that was non-significant $(\mathrm{P}=0.16)$. The best model for P. marmoratus (Iguanidae) included plant height (shortest and tallest), the diameter of the tallest plant, leaf litter depth, and canopy cover $\left(\mathrm{R}^{2}=0.71 ; \mathrm{F}(5,14)=6.7 ; \mathrm{P}=0.002 ; \mathrm{DF}=5\right.$ and 14 ; $\mathrm{AIC}=29.25$; Table SII). Significant values were obtained only for plant height $(\mathrm{P}=0.0002)$ and leaf litter depth $(\mathrm{P}=0.005)$.

\section{DISCUSSION}

The lizard species richness recorded in the present study was relatively high in comparison with similar studies based on a Rapid Assessment Program (RAP) approach (Rocha et al. 2014). Our study periods were longer and sampling effort was more intense, however, which contributed to the registration of four additional species, $O \mathrm{cf}$. striatus, S. merianae, L. lutzae and P. marmoratus. While at least two of these species ( $S$. merianae and $P$. marmoratus) are relatively common on Brazilian sandy coastal plains (Castro and SilvaSoares 2016), our results highlight the importance of longer sampling periods to ensure a reliable record of the composition of lizard communities. In fact, our accumulation curves revealed that our sampling effort was essential to the analysis of the assemblages (see Figure 3), even though this analysis indicated that we did not record the total number of species known to occur in the coastal ecosystems of Espírito Santo (e.g., Ecpleopus gaudichaudii, Iguana iguana, Dactyloa punctata, and Strobilurus torquatus: Castro and Silva-Soares 2016, Oliveira and Castro 2017).

As expected, we recorded some widelydistributed species (e.g., T. torquatus, A. ameiva, $B$. agilis, and P. macrorhyncha), which were found at all sites, and three (L. lutzae, P. marmoratus and $K$. calcarata) that were restricted to a single site. The record of L. lutzae is the result of an experimental introduction at Praia das Neves (Soares and Araújo 2008). This species is endemic to the coast of Rio de Janeiro state, between Marambaia and Cabo Frio (Rocha et al. 2009). At Praia das Neves, $L$. lutzae is associated with the halophilic-psamophilic vegetation in the vegetation zone, the same type of habitat inhabited by its natural populations in Rio de Janeiro (Rocha 1991, Rocha et al. 2009). Polychrus marmoratus is common in forested environments, and is widely distributed in the Amazon and Atlantic Forests (e.g., Ávila-Pires 1995, Castro 
and Silva-Soares 2016). Kentropyx calcarata is also widely-distributed in the Amazon and Atlantic Forests (e.g., Ávila-Pires 1995, Sousa and Freire 2008), although Linhares, in the Rio Doce basin of Espírito Santo represents the southern limit of its range (Rocha 1998, Rocha et al. 2014).

We found no significant variation in the abundance of species among sites. As expected, only a few of the species ( $T$. torquatus, $A$. nativo and $A$. ameiva) dominated lizard abundance, while most other species are rare. This is a typical pattern in most ecological communities (e.g. Gaston and Blackburn 2000). In the specific case of lizard communities on sandy coastal plains, Rocha and Bergallo (1997) suggested that this pattern is probably related to the structure of these environments, and their exposure to high levels of solar radiation, which favors the occurrence of heliophilous organisms, such as lizards.

Species richness did not vary significantly among mesohabitats, although the lowest richness and abundance were recorded in the beach vegetation zone. By contrast, abundance was highest in the shrubby vegetation and open
Clusia zones (see Table II). The occurrence and distribution of lizard species typically reflect their ecological requirements and capacity for the exploitation of resources. In the present case, the herbaceous, shrubby or arboreal vegetation (Rocha and Bergallo 1997), and the occurrence and density of cacti and/or bromeliads are crucial as sites for thermoregulation (Vrcibradic and Rocha 2002). Some microhabitats are also fundamental for foraging and shelter (Rocha and Vrcibradic 1998). These factors determine the most favorable sites in each mesohabitat, according to the ecophysiology and behavior of each species. These factors are important determinants of the spatial structure of animal communities worldwide (e.g. Tilman 1999, Cottenie 2005, Ackerly et al. 2006).

Habitat structure is known to determine the variation in the composition of the communities of sandy coastal ecosystems (e.g. Rocha and Bergallo 1997), and our results indicate an association of specific taxa with specific mesohabitats and microhabitats. While the variables tested did not explain the composition of the communities, bromeliads were the most important microhabitats.

TABLE II

Abundance of each lizard species using the different mesohabitats at: Praia das Neves, Paulo Cesar Vinha State Park, Conceição da Barra Environmental Protection Area, Comboios Biological Reserve and Itaúnas State Park.

\begin{tabular}{ccccc}
\hline Lizard species & Beach zone & Shrubby zone & Open Clusia & Forest \\
\hline Ophiodes cf. striatus & 0 & 0 & 0 & 1 \\
Tropidurus torquatus & 9 & 207 & 663 & 2 \\
Hemidactylus mabouia & 2 & 21 & 14 & 8 \\
Ameiva ameiva & 1 & 37 & 137 & 0 \\
Ameivula nativo & 3 & 97 & 0 & 0 \\
Salvator merianae & 0 & 0 & 0 & 0 \\
Liolaemus lutzae & 2 & 0 & 0 & 2 \\
Kentropyx calcarata & 0 & 0 & 1 & 2 \\
Gymnodactylus darwinii & 0 & 0 & 24 & 0 \\
Brasiliscincus agilis & 0 & 51 & 14 & 0 \\
Psychosaura macrorhyncha & 0 & 29 & 0 & 3 \\
\hline Polychrus marmoratus & 0 & 0 & 0 \\
\hline
\end{tabular}




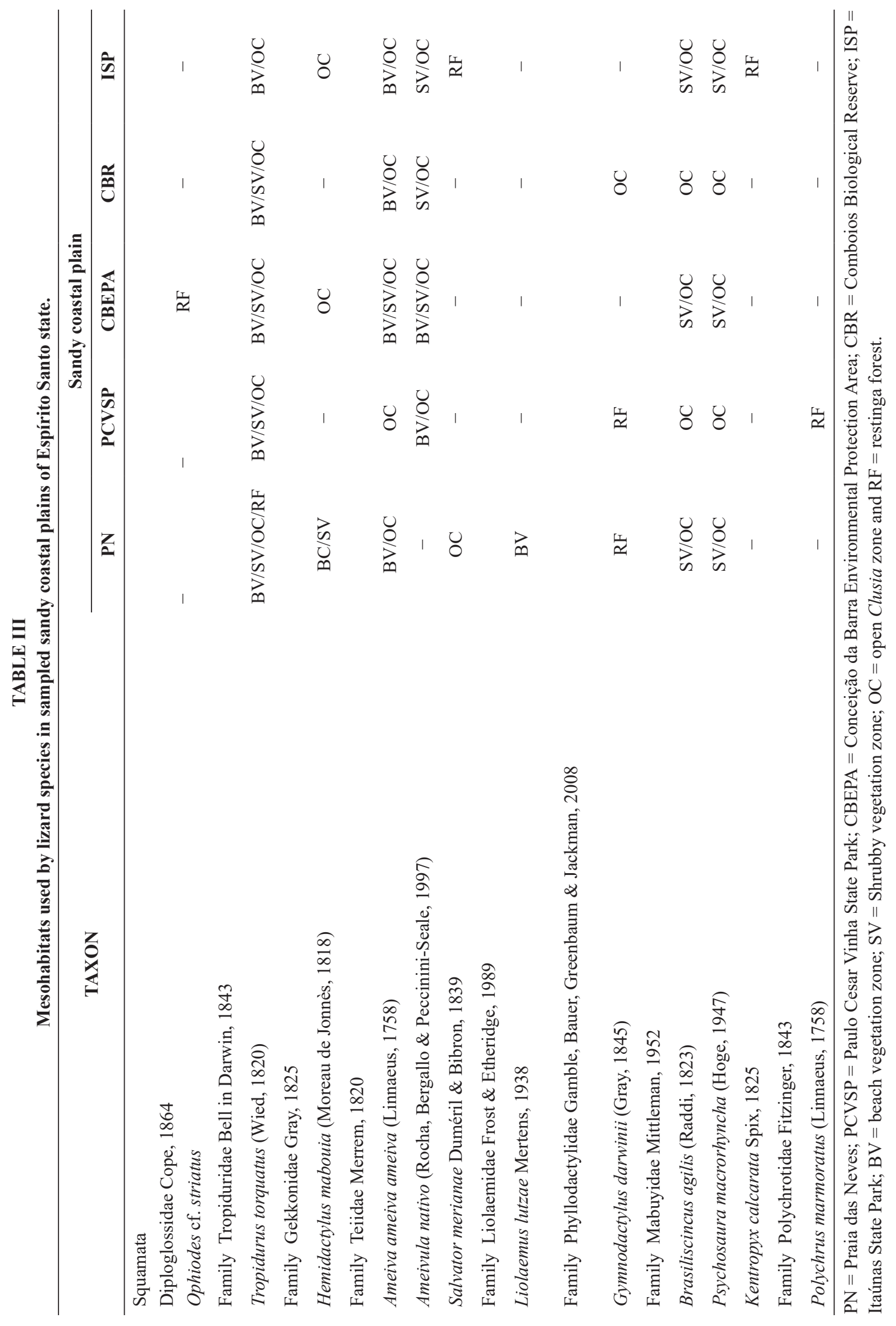


This association is probably at least partly associated with causal factors such as the habitats in which these species forage and the principal concentrations of bromeliads. In general, teiid lizards, such as Ameivula nativo, move through the habitat, foraging actively at the edge of the vegetation or in the bushes, while Ameiva ameiva tends to forage actively in denser shrubby vegetation (Araújo 1984, Rocha and Bergallo 1997). Shrubby vegetation on sandy coastal plains tends to have an abundance of bromeliads, and this habitat provides cover from predators, especially those for the juveniles (A. ameiva) and the smaller-bodied adults (A. nativo). The leaf litter found under bromeliads also harbors an abundant fauna of invertebrates and small vertebrates, providing potential prey for these lizards (Araújo 1984). This association is clearest, for example, in open Clusia mesohabitats, which has the greatest diversity and density of bromeliads in the coastal restinga (Rocha-Pessoa et al. 2008), and in our study, the greatest abundance of lizards. It thus seems likely that bromeliads represent important microhabitats for the structuring of the lizard communities on the sandy coastal plains, in particular teiids.

In our study, while the vegetation structure did not vary significantly among sites, bromeliads were the variable most closely associated with species richness and abundance. The strong association between the species composition and habitat structure indicates that local environmental factors have a major influence on the composition of communities (Parris 2004). Over geological time, the successive transgressions and regressions of sea levels determined the topography and vegetation structure of these sandy coastal plains (see Cerqueira 2000, Rocha et al. 2003), which may have been fundamental to processes such as speciation and extinctions, and in particular the formation of species assemblage (see Losos 1994). In this context, evolutionary and historical processes, combined with local ecological factors, have determined the present structure of the lizard communities found on these sandy coastal plains.

We found that the different lizard assemblages on the sandy coastal plains of Espírito Santo state are similar in their structure (species richness and composition), with their variations reflecting differences in the local environment. These findings have important implications for the conservation of these lizard assemblages, at different scales. The occurrence of species in different mesohabitats reinforces the importance of integrated conservation measures that prioritize the management of the different mesohabitats found within the ecosystem. Otherwise, the selective suppression of specific portions (mesohabitats) of the coastal plain would have an immediate impact on the structure of the local lizard assemblages.

\section{ACKNOWLEDGMENTS}

This study was supported by grants from Conselho Nacional de Desenvolvimento Científico e Tecnológico (CNPq - processes Nos. 304791/2010-5, 472287/2012-5 and 302974/20156) and Fundação Carlos Chagas Filho de Amparo à Pesquisa do Estado do Rio de Janeiro (FAPERJ) to CFDR ("Programa Cientistas do Nosso Estado" - Process No. E-26/102.765.2012 and E- 26/202.920.2015). JCFO thanks Coordenação de Aperfeiçoamento de Pessoal de Nível Superior (CAPES) for providing a graduate stipend and also FAPERJ for a current postdoctoral fellowship (Process E-26/202.388/2017). GRW thanks CNPq for a postdoctoral fellowship (process $n$. 151984/2016-6), and JPR thanks CAPES for a masters' scholarship fund.

\section{REFERENCES}

ACKERLY DD, SCHWILK DW AND WEBB CO. 2006. Niche evolution and adaptive radiation: Testing the order of trait divergence. Ecology 87(7): 550-561.

ARAÚJO AFB. 1984. Padrões de divisão de recursos em uma comunidade de lagartos de restinga. In: Lacerda 
LD, Cerqueira R and Turcq B (Eds), Restingas: origem, estrutura e processos. Niterói: CEUFF, p. 327-342.

ARAÚJO DSD AND HENRIQUES RBP. 1984. Análise florística das restingas do Estado do Rio de Janeiro. In: Lacerda LD, Cerqueira R and Turcq B (Eds), Restingas: origem, estrutura e processos. Niterói: CEUFF, p. 159-193.

ÁVILA-PIRES TCS. 1995. Lizards of brazilian Amazonia (Reptilia: Squamata). Zool Verhandel 299: 1-706.

BASTAZINI CV, MUNDURUCA JFV, ROCHA PLB AND NAPOLI MF. 2007. Which environmental variables better explain changes in anuran community composition? A case study in the restinga of Mata de São João, Bahia, Brazil. Herpetologica 63: 459-471.

BURNHAM KP AND ANDERSON DR. 2004. Multimodel inference: Understanding AIC and BIC in model selection. Socio Meth Res 33: 261-304.

CAMPBELL HW AND CHRISTMAN SP. 1982. Field techniques for herpetofaunal community analysis. In: Herpetological communities: a symposium of the society for the study of amphibians and reptiles and the herpetologist's league. Washington, U.S. Fish Wildlife Service, p. 193-200.

CASTRO TM AND SILVA-SOARES. 2016. Répteis da restinga do Parque Estadual Paulo César Vinha, Guarapari, Espírito Santo, Sudeste do Brasil. Cachoeiro de Itapemirim: Universidade São Camilo, 192 p.

CERQUEIRA R. 2000. Biogeografia das Restingas. In: Esteves FA and Lacerda LD (Eds), Ecologia de Restingas e Lagoas Costeiras. Rio de Janeiro: NUPEM/UFRJ, p. 65-67.

CLARKE KR. 1993. Non-parametric multivariate analyses of changes in community structure. Aust J Ecol 18: 117-143.

COLWELL RK. 2005. EstimateS: Statistical estimation of species richness and shared species from samples. Version 8. Available at: http://purl.oclc.org/estimates.

COTTENIE K. 2005. Integrating environmental and spatial processes in ecological community dynamics. Ecol Lett 8: 1175-1182.

DIAS EJR AND ROCHA CFD. 2014. Habitat Structural Effect on Squamata Fauna of the Restinga Ecosystem in Northeastern Brazil. An Acad Bras Cienc 86(1): 359-371.

FREITAS SR, CERQUEIRA R AND VIEIRA MV. 2002. A device and standard variables to describe microhabitat structure of small mammals based on plant cover. Braz $\mathrm{J}$ Biol 62(4): 795-200.

GASTON KJ AND BLACKBURN TM. 2000. Pattern and process in macroecology. Oxford: Blackwell Publishing, $392 \mathrm{p}$.

HAMMER O, HARPER DAT AND RYAN PD. 2001. PAST: Paleontological Statistics software package for education and data analysis. Paleontologia Eletronica 4(1): 9.

HANSKI I. 1994. Patch occupancy dynamics in fragmented landscapes. Trends Ecol Evolut 9: 131-135.
HATANO FH, VRCIBRADIC D, GALDINO CAB, CUNHABARROS M, ROCHA CFD AND VAN SLUYS M. 2001. Thermal ecology and activity patterns of the lizard community of the Restinga of Jurubatiba, Macaé, RJ. Braz J Biol 61(2): 287-294.

LOSOS J. 1994. Historical contigency and lizard community ecology. In: Vitt LJ and Pianka ER, Lizard Ecology: Historical and Experimental Perspectives. Princenton: Princeton University Press, p. 319-333.

MAGURRAN AE. 2011. Medindo a diversidade biológica. Curitiba: Editora da UFPR, 261 p.

MOUQUET N AND LOREAU M. 2003. Community patterns in source-sink metacommunities. Am Nat 162: 544-557.

NEKOLA JC AND WHITE PS. 1999. The distance decay of similarity in biogeography and ecology. J Biogeogr 26: 867-878.

OLIVEIRA JCF AND CASTRO TM. 2017. Range extension of Iguana iguana Linnaeus, 1758 (Squamata: Iguanidae): the first record of an established population in southeastern Brazil. Check List 13(2): 2097.

OLIVEIRA JCF, WINCK GR, PEREIRA-RIBEIRO J AND ROCHA CFD. 2017. Local Environmental Factors Influence the Structure of Frog Communities on the Sandy Coastal Plains of Southeastern Brazil. Herpetologica 73(4): 307-312.

PARRIS KM. 2004. Environmental and spatial variables influence the composition of frogs assemblages in subtropical eastern Australia. Ecography 27(3): 392-400.

PEREIRA OJ. 1990. Caracterização fitofisionômica da restinga de Setiba - Guarapari/ES. In: ACIESP (Eds), II Simpósio de ecossistemas da costa Sul e Sudeste brasileira: estrutura, função e manejo. Águas de Lindóia 3: 207-219.

PULLIAM HR. 2000. On the relationship between niche and distribution. Ecol Lett 3: 349-361.

ROCHA CFD. 1991. Composição do hábitat e uso do espaço por Liolaemus lutzae (Sauria: Tropiduridae) em uma área de restinga. Rev Bras Biol 51(4): 839-846.

ROCHA CFD. 1998. Composição e Organização da Comunidade de Répteis da Área de Mata Atlântica da Região de Linhares, Espírito Santo. Anais do VIII Seminário Regional de Ecologia (7): 869-881.

ROCHA CFD AND BERGALLO HG. 1997. Intercommunity Variation in the Distribution of Abundance Lizards Species in Restinga Habitats. Ciênc Cult 4: 269-274.

ROCHA CFD, BERGALLO HG, ALVES MAS AND VAN SLUYS M. 2003. Diagnóstico do estado de Conservação da biodiversidade das restingas do corredor da Serra do Mar e do Corredor Central da Mata Atlântica. In: A Biodiversidade nos Grandes Remanescentes Florestais do Estado do Rio de Janeiro e nas Restingas da Mata Atlântica. São Carlos: RIMA, 160 p.

ROCHA CFD, SIQUEIRA CC AND ARIANI CV. 2009. The endemic and threatened lizard Liolaemus lutzae (Squamata: 
Liolaemidae): current geographic distribution and areas of occurrence with estimated population densities. Zoologia 26(3): 454-460.

ROCHA CFD, VAN SLUYS M, BERGALLO HG AND ALVES MAS. 2005. Endemic and threatened tetrapods in the restinga of the biodiversity corridors of Serra do Mar and the Central da Mata Atlântica in eastern Brazil. Braz J Biol 65(1): 159-168.

ROCHA CFD AND VRCIBRADIC D. 1998. Reptiles as predators of vertebrates and as preys in a restinga habitat of southeastern Brazil. Cienc Cult 50(5): 354-368.

ROCHA CFD, VRCIBRADIC D, KIEFER MC, MENEZES VA, FONTES AF, HATANO FH, GALDINO CAB, BERGALLO HG AND VAN SLUYS M. 2014. Species composition, richness and nestedness of lizard assemblages from Restinga habitats along the Brazilian coast. Braz J Biol 74(2): 349-354.

RSTUDIO TEAM. 2015. RStudio: Integrated Development for R. RStudio, Inc., Boston, MA. Available at: http:// www.rstudio.com/.

SOARES AH AND ARAÚJO AFB. 2008. Experimental introduction of Liolaemus lutzae (Squamata: Iguanidae) in Praia das Neves, State of Espírito Santo, Brazil: a descriptive study 18 years later. Rev Bras Zool 25(4): 640646.

SOUSA PAG AND FREIRE EMX. 2008. Kentropyx calcarata: Geographic Distribution. Herpetol Rev 39: 238.

SUGUIO K AND TESSLER MG. 1984. Planícies de cordões litorâneos quaternários do Brasil: origem e nomenclatura.
In: Restingas: Origem, Estrutura e Processos. Rio de Janeiro: Universidade Federal Fluminense - UFF, p. 1525.

SUTHERLAND ET AL. 2013. Identification of 100 fundamental ecological questions. J Ecol 101: 58-67.

TILMAN D. 1999. The ecological consequences of changes in biodiversity: a search for general principles. Ecology 80(5): 1455-1474.

VITT LJ, COLLI GR, CALDWELL JP, MESQUITA DO, GARDA AA AND FRANÇA FGR. 2007. Detecting variation in microhabitat use in low-diversity lizard assemblages across small-scale habitat gradients. J Herpetol 41(4): 654-663.

VRCIBRADIC D AND ROCHA CFD. 2002. Use of cacti as heat sources by thermoregulating Mabuya agilis (Raddi) and Mabuya macrorhyncha Hoge (Lacertilia, Scincidae) in two restinga habitats in southeastern Brazil. Rev Bras Zool 19(1): 77-83.

WEDIN D AND TILMAN D. 1990. Competition among grasses along a nitrogen gradient: initial conditions and mechanisms of competition. Ecol Monogr 63: 199-229.

\section{SUPPLEMENTARY MATERIAL}

Table SI - Mantel values for comparisons between pairs of restingas in relation to the habitat structure.

Table SII - Best models results relating lizard abundance and habitat structure. 